\title{
HAK PENDIDIKAN DI WILAYAH PERBATASAN DALAM KERANGKA KONSTITUSI REPUBLIK INDONESIA
}

\author{
Dr. Endah Rantau Itasari \\ Fakultas Hukum \\ Universitas Tanjungpura Pontianak \\ Email : itafira@yahoo.com
}

\begin{abstract}
Abstrak
Kewajiban negara berkaitan dengan HAM adalah untuk melindungi, memajukan, memenuhi dan menghormati. Berkaitan dengan hak atas pendidikan kewajiban negara tersebut berkaitan dengan segala upaya agar hak tersebut dapat dinikmati oleh semua orang tanpa diskriminasi atau memerangi semua ketidakadilan yang ada dalam mengakses dan menikmati pendidikan. Kewajiban negara ini dapat diwujudkan melalui pembuatan peraturan-peraturan ataupun cara-cara lain untuk memajukan persamaan kesempatan dan perlakuan dalam pendidikan sebagaimana ditetapkan dalam Konvensi Melawan Diskriminasi dalam Pendidikan yang disepakati oleh Konferensi Umum UNESCO pada tanggal 14 Desember 1960. Dengan kebijakan pemerintahan saat ini yang ingin memulai pembangunan dari wilayah perbatasan dan wilayah terluar semestinya kondisi pemenuhan hak atas pendidikan bagi masyarakat di wilayah perbatasan menjadi salah satu prioritas. Dengan demikian diperlukan sebuah kajian untuk mendapatkan gambaran mengenai politik hukum dan kebijakan negara dalam memenuhi hak atas pendidikan dasar dan menengah bagi masyarakat di perbatasan Kalimantan Barat dengan Sarawak. Analisis situasi dan kebutuhan terhadap pemenuhan hak atas pendidikan dasar dan menengah di wilayah perbatasan negara di Provinsi Kalbar perlu dilakukan secara menyeluruh terhadap kebijakan, program, kegiatan dan pendanaan dalam pemenuhan hak atas pendidikan.
\end{abstract}

Kata kunci : Pendidikan, Konstitusi, Hak Asasi Manusia

\begin{abstract}
The state's obligation related to human rights is to protect, advance, fulfill and respect. With regard to the right to education, the obligations of the state relate to all efforts so that these rights can be enjoyed by all people without discrimination or to combat all injustices that exist in accessing and enjoying education. The obligations of this country can be realized through the making of regulations or other ways to advance equality of opportunity and treatment in education as stipulated in the Convention Against Discrimination in Education agreed by the General Conference of UNESCO on December 14, 1960. With current government policies wishing start the development of the border region and the outermost area should the condition of fulfilling the right to education for people in the border region be one of the priorities. Thus, a study is needed to get an overview of the legal politics and state policies in fulfilling the right to primary and secondary education for people on the border of West Kalimantan with Sarawak. Analysis of the situation and the need for the fulfillment of the right to
\end{abstract}


Jurnal Media Komunikasi Pendidikan Pancasila dan Kewarganegaraan

Volume 2, Nomor 1 April 2020

primary and secondary education in the country's border regions in West Kalimantan Province needs to be carried out thoroughly of policies, programs, activities and funding in the fulfillment of the right to education.

\section{Keywords: Education, Constitution, Human Rights}

\section{Pendahuluan}

Dalam Pembukaan UUD 1945 ditegaskan bahwa salah satu tujuan dibentuknya pemerintahan Negara Indonesia adalah "untuk mencerdaskan kehidupan bangsa". Tujuan ini kemudian dimanifestasikan melalui Pasal 28C ayat (1) dan Pasal 31 UUD 1945 dan dijabarkan lebih lanjut dalam berbagai peraturan perundangundangan termasuk Undang-Undang No. 20 Tahun 2003 tentang Sistem Pendidikan Nasional sebagai lex specialis. Berkaitan dengan ICESCR, Indonesia telah meratifikasi kovenan tersebut pada tanggal 30 September 2005 melalui Undang-Undang Nomor 11 Tahun 2005 tentang Pengesahan theInternational Covenant on Economic, Social and Cultural Rights. Dalam ICESCR sendiri hak atas pendidikan khususnya diatur dalam Pasal 13 dan Pasal 14.

Hakekat hak atas pendidikan pada tingkat pendidikan dasar, sebagaimana ditegaskan dalam ICESCR, merupakan suatu kondisi tertentu harus diciptakan oleh negara peratifikasi. Aspek substansi pendidikan dan manajerial penyelenggaraan pendidikan merupakan elemen dasar dalam Pasal 13 ICESCR bagi negara untuk menyediakan pendidikan dasar bagi setiap orang. Aspek ketersediaan dan kemudahan sarana dan prasarana pendidikan, dan aspek penerimaan dan daya penyesuaian merupakan segmen-segmen hukum (indikator) yang harus dikondisikan pemenuhannya secara bertahap oleh negara untuk setiap saat dicapai dan ditingkatkan pemenuhannya dalam bidang pendidikan, khususnya pendidikan dasar dan menengah (Freeman, "The Limits of Children's Rights, dalam The Ideologies of Children's Rights, 1992).

Indonesia sebagai pihak pada ICESCR terikat untuk melaksanakan ketentuan-ketentuan tersebut berdasarkan kewajiban-kewajian internasional yang terkandung didalamnya (Santos Pais, "A Human Rights Conceptual Framework for Children's Rights ). Bonanza Perwira Taihitu memberikan kerangka argumentatif bahwa politik hukum nasional Indonesia terhadap pelaksanaan ketentuan-ketentuan hukum hak asasi manusia internasional tersebut di atas antara tahun 1990 sampai dengan akhir tahun 2005 lebih cenderung bersifat sebagai sebuah pencitraan nasional di forum internasional (Taihitu, 2003). Dengan demikian, kewajibankewajiban dasar dalam ketentuan tersebut dilaksanakan untuk lebih menarik simpati luar negeri dari pada pemanfaatannya untuk kepentingan nasional.

Menjadi menarik untuk dikaji apakah sifat dan tujuan politik hukum nasional di Indonesia terhadap pemenuhan hak atas pendidikan, khususnya pendidikan dasar dan menengah setelah 
Jurnal Media Komunikasi Pendidikan Pancasila dan Kewarganegaraan

Volume 2, Nomor 1 April 2020

amandemen UUD 1945. Motivasi tersebut apakah menjiwai terhadap implementasi ICESCR menjadi suatu kajian yuridis yang kaya makna. Kajian yuridis tersebut terkait dengan 11 kluster temuan permasalahan pemenuhan hak atas pendidikan oleh Kementerian Pendidikan dan Kebudayaan Republik Indonesia (Kemdikbud RI) (Biro Hukum dan Organisasi Setjen Kemdikbud). Salah satu kluster permasalahan tersebut adalah permasalahan pemenuhan hak anak atas pendidikan dasar dan menengah di wilayah perbatasan Indonesia dengan wilayah lainnya seperti dengan Malaysia, Papua Nugini (PNG) dan Republic Demokratik Timor Leste (RDTL).

Provinsi Kalimantan Barat (Kalbar) telah dijadikan telaah kajian dan inisiasi peningkatan pemenuhan hak atas pendidikan oleh Kemdikbud sejak tahun 2009 khususnya di wilayah perbatasan dengan Malaysia. Minimnya sarana dan prasarana, rendahnya keinginan bersekolah, keengganan pelaku pendidikan melaksanakan tugas dan fungsi pendidik dan rendahnya alokasi dana pendidikan telah menyebabkan ketertinggalan dan ketimpangan memperoleh akses pendidikan di wilayah-wilayah perbatasan tersebut (Marzuki,;2011).

Sebagian besar wilayah perbatasan Kalimantan Barat dengan Sarawak, Malaysia juga termasuk sebagai Daerah Tertinggal, Terdepan dan Terluar (D3T) yang saat ini menjadi prioritas pembangunan sesuai dengan visi Nawacita dari Presiden Joko Widodo. Pada tahun 2015, telah ditetapkan 122 kabupaten sebagai daerah tertinggal dan 43 daerah terdepan dan terluar berdasarkan Surat No. 2421/Dt.7.2/04/2015 tanggal 21 April 2015 oleh Kementerian Perencanaan Pembangunan Nasional/Badan Perencanaan Pembangunan Nasional (Kemen PPN/BAPPENAS). Dalam daftar tersebut Kabupaten Sambas, Kabupaten Bengkayang, Kabupaten Sintang dan Kabupaten Kapuas Hulu termasuk dalam D3T.

Untuk mengatasi pemenuhan hak pendidikan di wilayah D3T ini, berbagai kebijakan sebenarnya telah dilakukan oleh pemerintah, salah satunya adalah dengan program Sarjana Mengajar di Daerah Terdepan, Terluar dan Tertinggal (SM-3T) untuk mengatasi kekurangan pengajar di daerah perbatasan. Gerakan SM-3T merupakan solusi dari permasalahan kurangnya tenaga pendidik di D3T. Dari gerakan tersebut para lulusan S1 kependidikan dapat mentransfer ilmunya kepada orang-orang yang memang benar-benar membutuhkan. Dalam gerakan tersebut para pendidik dikirim ke daerah D3T yang ada di luar pulau jawa terutama di bagian timur Indonesia seperti pedalaman Kalimantan, Sulawesi, Papua dan lain sebagainya.

Manfaat dari hadirnya gerakan tersebut selain untuk membantu kurangnya tenaga pendidik di D3T juga untuk mempersiapkan tenaga pendidik yang tangguh, mandiri dan berkompetensi serta memiliki pengetahuan yang luas mengenai kondisi pendidikan di Indonesia sehingga dengan secara sadar calon pendidik tersebut dapat memanfaatkan ilmunya dengan baik untuk membangun dan 
mencerdaskan bangsa. Selain itu dengan adanya gerakan tersebut juga bermanfaat untuk menciptakan tenaga pendidik yang memiliki jiwa sosial yang tinggi karena dengan pengalaman mengikuti gerakan tersebut calon pendidik ikut merasakan kehidupan orang-orang di D3T sehingga tergerak jiwanya untuk dapat memperbaiki kehidupan mereka melalui jalur pendidikan.

Namun demikian, program SM3T juga menghadapi beberapa kendala terutama adalah kurangnya minat mahasiswa dan sarjana kependidikan untuk mengikuti program ini. Sebagai contoh di Universitas Pendidikan Indonesia (UPI) yang merupakan salah satu dari 17 perguruan tinggi yang menyelenggarakan program SM-3T, pada gelombang pertama hanya mengirimkan 66 peserta dan pada gelombang kedua jumlahnya turun menjadi 64 peserta. Padahal UPI mendapat kuota sebanyak 300 peserta (Fitriyani, 2013).

Dengan kondisi demikian pula, menjadi relevan untuk mengkaji regulasi, kebijakan dan program serta alokasi anggaran yang ditetapkan pemerintah, baik pusat maupun daerah, di sektor pendidikan memenuhi asas ketersediaan (availibility), kesempatan memperoleh (accessability), asas penerimaan (acceptability) dan asas penyesuaian (adaptability) berdasarkan kondisi senyatanya, terutama di wilayah perbatasan yang termasuk dalam D3T tersebut.

Permasalahan tersebut ternyata memiliki persamaan dengan permasalahan di Papua, khususnya di wilayah perbatasan dengan Papua New Guinea (PNG) dan di Nusa
Tenggara Timur, khususnya di wilayah Atambua yang berbatasan dengan Republik Demokratik Timor Leste (RDTL). Namun demikian, perbatasan Kalimantan Barat dan Malaysia memiliki perbedaan dengan perbatasan dengan PNG maupun RDTL karena Malaysia memiliki tingkat kesejahteraan dan kemajuan yang berada di atas Indonesia, termasuk pada sektor pendidikan. Hal ini sedikit banyak mempengaruhi kondisi pendidikan di wilayah perbatasan Kalimantan Barat dengan Sarawak, Malaysia di mana fenomena anak-anak warga negara Indonesia yang turut menikmati fasilitas pendidikan Malaysia dapat ditemui pada beberapa daerah. Fenomena ini merupakan cerminan bagaimana keterbatasan kehadiran negara di wilayah perbatasan kemudian disikapi masyarakat perbatasan dengan mencari pemenuhan pelayanan dasar termasuk hak pendidikan kepada negara tetangga.

Dalam tataran normatif, untuk memastikan pemenuhan kebutuhan masyarakat akan pendidikan yang layak, negara mempunyai kewajiban untuk memastikan penyedian sistem pendidikan dan kurikulum yang memadai, penyediaan beasiswa, penyediaan sarana dan prasarana yang memadai, meningkatkan kualitas tenaga pendidik baik guru maupun dosen di perguruan tinggi (Committee on Economic, Social and Cultural Rights ). Menurut kewajiban yang terkandung dalam ICESCR, sistem pendidikan yang ditetapkan oleh pemerintah harus dapat menjangkau semua warganegara, dapat diakses secara bebas tanpa diskriminasi dan secara ekonomi dan 
psikologis dapat diterima, serta sifatnya dapat menyesuaikan diri dengan perkembangan zaman (Wringe, 2006).

Putusan Mahkamah Konstitusi dalam Perkara Nomor 012/PUUIII/2005 Mengenai Pengujian UU No. 36 Tahun 2004 Tentang APBN terhadap pengakuan, pemajuan dan perlindungan hak asasi manusia dalam bidang pendidikan mempertegas perdebatan lama yang tidak kunjung akhir mengenai kewajiban negara terhadap pemenuhan hak ekonomi, sosial dan budaya seperti yang termaktub dalam Konvenan (Triyana;2006).

Persoalan-persoalan seperti akses terhadap pendidikan, pengurangan siswa putus sekolah, penguatan dan dukungan atas institusi-institusi pendidikan dasar umum dan khusus yang sudah ada dan penanganan akses pendidikan di wilayah terpencil belum tertanggulangi secara nyata.

Di Provinsi Kalimantan Barat, kendala geografis dengan disparitas dan kontur alam berupa hutan dan perbukitan menyebabkan akses terhadap pendidikan menjadi kurang sehingga keterjangkauan menjadi rendah, terutama di wilayah-wilayah yang berbatasan langsung dengan Malaysia seperti di Entikong dan Sambas. Meskipun di beberapa level nampak terlihat adanya upaya-upaya Pemerintah Pusat dan Pemerintah Daerah Provinsi Kalbar untuk menangani persoalan-persoalan tersebut, namun demikian langkahlangkah penanganan tersebut masih belum fokus baik dalam aspek kualitas dan kuantitas sarana dan prasarana.
Pemerintah masih belum serius menangani masalah akses pendidikan di Kalimantan Barat, Kalimantan Barat merupakan provinsi yang sebagian besar terdiri atas perairan. Maka akses antar daerah di Kalimantan Barat sebagian besar menggunakan transportasi sungai. Oleh karena itu, pemerintah harus dapat memaksimalkan transpotasi yang ada di Kalimantan Barat seperti jembatan, dermaga, serta sarana prasarana pendukung lainnya. Intinya pemerintah harus memberikan perhatian khusus bagi lembaga pendidikan yang berdomisili di daerah yang memiliki keterbatasan akses pendidikan. Solusi yang terbaik adalah perluasan akses pendidikan serta pemerataan layanan pendidikan baik di daerah terpencil maupun di daerah perkotaan.

Dengan kebijakan pemerintahan saat ini yang ingin memulai pembangunan dari wilayah perbatasan dan wilayah terluar semestinya kondisi pemenuhan hak atas pendidikan bagi masyarakat di wilayah perbatasan menjadi salah satu prioritas. Dengan demikian diperlukan sebuah kajian untuk mendapatkan gambaran mengenai politik hukum dan kebijakan negara dalam memenuhi hak atas pendidikan dasar dan menengah bagi masyarakat di perbatasan Kalimantan Barat dengan Sarawak. Analisis situasi dan kebutuhan terhadap pemenuhan hak atas pendidikan dasar dan menengah di wilayah perbatasan negara di Provinsi Kalbar perlu dilakukan secara menyeluruh terhadap kebijakan, program, kegiatan dan pendanaan dalam pemenuhan hak atas pendidikan. 
Pelaksanaan indikator-indikator tersebut akan menghasilkan akuntabilitas dan legitimasi yang dapat diterima khususnya dalam implementasi instrumen-instrumen hukum internasional yang telah diratifikasi Indonesia. Secara teoritis praktis, indikator legal pelaksanaan tersebut di atas dapat diukur melalui sistematisasi pada budaya hukum (legal culture); struktur hukum (legal structure) dan substansi hukum (legal substance) terhadap upaya pemenuhan hak atas pendidikan. Daya paksa berlakunya hukum akan memperoleh justifikasi legal, sosial dan politik sehingga pemberlakuan ini dapat digunakan sebagai referensi bagi pemenuhan hak atas pendidikan dasar dan menengah di wilayah perbatasan negara yang lainnya yaitu di Papua dan di NTT. Dalam penelitian ini akan dibahas tentang Hak Pendidikan di Wilayah Perbatasan Dalam Kerangka Konstitusi Republik Indonesia.

\section{Pembahasan}

\section{Hak Asasi Manusia Sebagai Hak} Yang Fundamental dan Universal

Konsep Hak Asasi Manusia (HAM) mencakup tiga elemen utama bagi eksistensi manusia baik sebagai mahkluk individu dan mahkluk sosial yaitu integritas manusia (human integrity), kebebasan (freedom) dan kesamaan (equality) (Allan Rosas, 1995). Ketiga elemen tersebut dikonseptualisasikan ke dalam pengertian-pengertian dan pemahaman tentang apa itu HAM.

Pemahaman atas pengertian ini menjadi jelas ketika pengakuan atas hak tersebut diberikan dan dipandang sebagai proses humanisasi manusia oleh pihak lain dalam konteks vertikal (individu dengan negara) dan horisontal (antar individu) baik secara de facto maupun de jure. Dengan demikian, nilai-nilai HAM itu bersifat fundamental dan universal dengan adanya pengakuan, perlindungan dan pemajuan terhadap integritas, kebebasan dan kesamaan manusia dalam instrumen-instrumen pokok HAM internasional, baik di tingkat internasional, regional dan nasional. Walaupun nilai-nilainya bersifat universal, HAM dapat dibedakan ke dalam beberapa pengelompokan akademis normatif yaitu, pertama, hak-hak asasi pribadi atau "personal rights". Kedua, hakhak azasi ekonomi atau hak untuk memiliki sesuatu ("property rights"). Ketiga, hak untuk mendapatkan perlakuan yang sama dan sederajat dalam hukum dan pemerintahan atau "right of legal equality". Keempat, hak-hak asasi politik atau "political rights". Kelima, hak-hak asasi sosial dan kebudayaan atau "social and cultural rights", seperti memperoleh dan memilih pendidikan, mengembangkan kebudayaan yang disukai. Keenam, hak berperkara dan perlindungan atasnya atau "procedural rights". Pengertian dan pemahaman HAM dari segi substansi ini menjadi pelik dan kompleks berdasarkan perkembangan, realitas yang ada dan kompleksitas faktorfaktor determinan lainnya.

Konsep dan nilai-nilai HAM berubah dan sejalan dengan waktu baik melalui proses evolusioner dan revolusioner dari kekuatan normatif kedalam proses perubahan sosial dan politik pada seluruh tatanan kehidupan manusia (Perwira,2003). Dengan demikian, pengertian dan pemahaman akan arti HAM dalam 
artian substansi harus dikembalikan pada konsep dasar kenapa HAM itu ada. HAM itu ada dan muncul karena hak-hak asasi tersebut sifatnya sangat mendasar atau asasi (fundamental) dalam pengertian bahwa pelaksanaannya mutlak diperlukan agar manusia dapat berkembang sesuai dengan bakat, cita-cita, serta martabatnya sebagai manusia tanpa memandang perbedaan-perbedaan yang menyebabkan diskriminasi berdasarkan bangsa, ras, agama dan jenis kelamin. Prinsip-prinsip pemahaman HAM harus dijadikan pijakan utama sehingga pengertian dan pemahaman HAM dari segi substantif menjadi aplikatif. Prinsipprinsip tersebut adalah aplikasi dari konsep the indivisibility dan the interdependence dari nilai-nilai HAM itu sendiri (UNICEF, 1998).

Menurut ontologinya, HAM adalah hak yang dimiliki oleh manusia yang diperoleh dan dibawanya bersamaan dengan kelahiran atau kehadirannya di dalam kehidupan masyarakat karena ia mempunyai suatu keistimewaan yang membuka kemungkinan baginya untuk diperlakukan sesuai dengan keistimewaan tersebut (Huijbers, 1990). Dengan pengertian yang lebih sederhana, HAM adalah hak seseorang yang jika hak tersebut diambil dari dirinya akan mengakibatkan orang tersebut menjadi bukan manusia lagi (United Nations, 1998).

Hak asasi manusia, sebagaimana yang dipahami di dalam dokumendokumen hak asasi manusia yang muncul pada abad kedua puluh seperti Deklarasi Universal Hak Azasi Manusia (DUHAM), mempunyai sejumlah ciri menonjol, yaitu: (James W., 1987) Pertama, supaya kita tidak kehilangan gagasan yang sudah tegas, hak asasi manusia adalah hak. Makna istilah ini tidak jelas, namun setidaknya kata tersebut menunjukkan bahwa itu adalah norma-norma yang pasti dan memiliki prioritas tinggi yang penegakannya bersifat wajib. Kedua, hak-hak ini dianggap bersifat universal, yang dimiliki oleh manusia semata-mata karena ia adalah manusia. Pandangan ini menunjukkan secara tidak langsung bahwa karakteristik seperti ras, jenis kelamin, agama, kedudukan sosial, dan kewarganegaraan tidak relevan untuk mempersoalkan apakah seseorang memiliki atau tidak memiliki hak asasi manusia. Ini juga menyiratkan bahwa hak-hak tersebut dapat diterapkan di seluruh dunia. Salah satu ciri khusus dari hak asasi manusia yang berlaku sekarang adalah bahwa itu merupakan hak internasional. Kepatuhan terhadap hak serupa itu telah dipandang sebagai obyek perhatian dan aksi internasional yang sah.

Ketiga, hak asasi manusia dianggap ada dengan sendirinya, dan tidak bergantung pada pengakuan dan penerapannya didalam sistem adat atau sistem hukum di negara-negara tertentu. Hak ini boleh jadi memang belum merupakan hak yang efektif sampai ia dijalankan menurut hukum, namun hak itu eksis sebagai standar argumen dan kritik yang tidak bergantung pada penerapan hukumnya. Keempat, hak asasi manusia dipandang sebagai normanorma yang penting. Meski tidak seluruhnya bersifat mutlak dan tanpa 
perkecualian, hak asasi manusia cukup kuat kedudukannya sebagai pertimbangan normatif untuk diberlakukan di dalam benturan dengan norma-norma nasional yang bertentangan, dan untuk membenarkan aksi internasional yang dilakukan demi hak asasi manusia. Hak-hak yang dijabarkan di dalam Deklarasi tersebut tidak disusun menurut prioritas; bobot relatifnya tidak disebut. Tidak dinyatakan bahwa beberapa di antaranya bersifat absolut.

Dengan demikian hak asasi manusia yang dipaparkan oleh Deklarasi itu adalah sesuatu yang oleh para filsuf disebut sebagai prima facie rights. Kelima, hak-hak ini mengimplikasikan kewajiban bagi individu maupun pemerintah. Adanya kewajiban ini, sebagaimana halnya hak-hak yang berkaitan dengannya, dianggap tidak bergantung pada penerimaan, pengakuan, atau penerapan terhadapnya. Pemerintah dan orangorang yang berada di mana pun diwajibkan untuk tidak melanggar hak seseorang, kendati pemerintah dari orang tersebut mungkin sekaligus memiliki tanggung jawab utama untuk mengambil langkahlangkah positif guna melindungi dan menegakkan hak-hak orang itu.Keenam, hak-hak ini menetapkan standar minimal bagi praktek kemasyarakatan dan kenegaraan yang layak. Tidak seluruh masalah yang lahir dari kekejaman atau pementingan diri sendiri dan kebodohan merupakan problem hak asasi manusia. Sebagai misal, suatu pemerintah yang gagal untuk menyediakan taman-taman nasional bagi rakyatnya memang dapat dikecam sebagai tidak cakap atau tidak cukup memperhatikan kesempatan untuk rekreasi, namun hal tersebut tidak akan pernah menjadi persoalan hak asasi manusia.

\section{Pendidikan Dalam Hak Asasi Manusia}

Pendidikan adalah hak asasi manusia dan telah memperoleh status sebagai salah satu hak asasi yang bersifat fundamental (Deklarasi Universal Hak Asasi Manusia 1948). Hak atas pendidikan tersebut merupakan bagian dari hak ekonomi, sosial, dan budaya, yang pemenuhannya merupakan bagian dari kewajiban negara kepada rakyatnya (Prasetyo;2009). Pada prinsipnya, setiap orang mempunyai hak yang sama untuk mengikuti pendidikan dan menikmati hasilhasilnya pada semua tingkatan pendidikan tanpa diskriminasi. Pemerintah harus meletakkan pendidikan sebagai hak dan menyebarluaskan pemahaman akan hal itu (diseminasi), memonitoring dan mengevaluasi atas pelaksanaannya (monitoring dan evaluasi), dan melaksanakan kebijakan-kebijakan berdasarkan dua langkah terdahulu tersebut secara nyata (adjudikasi) (Keppres Nomor 40 Tahun 2004).

Dilain sisi, Robert McCorquodale menguatkan asumsi yuridis bahwa hak atas pendidikan dalam sistem hukum internasional memiliki sifat dasar yang memaksa karena subyek-subyek hukum internasional, khususnya organisasi internasional secara konsisten menempatkan kewajiban pemenuhannya secara imperatif bagi anggotanya. Dasar argumentasinya 
adalah organisasi internasional memiliki kewajiban internasional terhadap perlindungan HAM, khususnya pemenuhan hak atas pendidikan berdasarkan 3 (tiga) argumen hukum, yaitu: (1). Organisasi internasional tidak boleh bertindak bertentangan dengan kewajiban hukum yang dimiliki oleh anggotanya terhadap kewajiban mereka pada instrumen perlindungan hukum HAM yang diterimanya, khususnya pemenuhan hak atas pendidikan; (2). Organisasi internasional terikat pada hukum kebiasaan internasional mengenai perlindungan HAM sama seperti pada negara dan individu dalam memenuhi hak atas pendidikan yang telah menjadi tujuan utama dari pendiriannya; dan (3). Kewajiban hukum perlindungan HAM tersebut telah berkembang ke organisasi internasional secara langsung (McCorquodale ;2009). Sebagai contoh mutakhir mengenai status hak atas pendidikan dalam sistem hukum internasional, Deklarasi HAM ASEAN mengambil ketiga argumen hukum ini sebagai rasionalitas dan fakta hukum pembentukan norma dan mekanisme pembentukan hak atas pembangunan (http://news.antara.co.id).

Sejalan dengan kedua argumentasi hukum tersebut di atas, Komite Hak Ekonomi, Sosial dan Budaya menyatakan bahwa: "State Parties should ensure that their actions as members of international organizatioions take due account of their rights to education. Accordingly, State parties that are members of international financial institutions, notably the International Monetary Fund, the World Bank, and regional development banks, should take steps to ensure that the right to education is taken into account in their lending policies, credit agreements and other international measures" (Committe on Economic, Social and Cultural Rights). Mudahnya, organisasi internasional terikat terhadap kewajiban pemenuhan dan perlindungan hak atas pendidikan dalam menjalankan fungsinya (Antwerp, 2004). Selain itu, yurisprudensi internasional juga menguatkan argumentasi tersebut di atas bahwa organisasi internasional memiliki kewajiban pemenuhan dan perlindungan HAM secara langsung berdasarkan aplikasi hukum kebiasaan internasional sebagai sebuah penghormatan atas Piagam PBB (Blokker and Schemers;2003).

Mahkamah Internasional (MI) dalam hal ini memutuskan secara jelas bahwa: "International organizations are subjects of international law and, as such, are bound by any obligations incumbent upon them under general rules of international law, under their constitutions or under international agreements to which they are parties" (Interpretation of the Agreement of March 25, 1951). Dengan demikian, status hak atas pendidikan adalah sebagai salah satu norma hukum yang memaksa yang keberadaanya tidak bisa disimpangi, dan mengharuskan negara-negara sebagai subyek hukum internasional wajib memenuhinya sebagai salah satu kewajiban internasional dalam perlindungan HAM pada umumnya. Dari status hukum yang demikian, hak atas pendidikan memiliki rasionalitas hukum yang dibangun dari keyakinan hukum yang 
ditunjukan dalam aturan-aturan normatif internasional dan praktekpraktek subyek hukum internasional sehingga memperoleh suatu legitimasi yang kuat (Lawson;1999).

Dalam perkembangan terkini, hak atas pendidikan merupakan salah satu hak asasi dasar yang memungkinkan setiap manusia bisa berperan aktif dalam pembangunan. Dalam Preamble of the Declaration on the Right to Development (http://www.unhchr.ch), asas-asas dasar yaitu partisipasi dan non diskriminasi menjadi dasar utama dalam pengembangan pendidikan seseorang berdasarkan kesamaan dalam hal Negara berperan dan wajib menyediakan pendidikan bagi semua orang, menjamin bahwa setiap orang memiliki akses terhadap pendidikan tanpa ada diskriminasi (Convention Against Discrimination in Education 1960), serta berkewajiban menghilangkan hambatan-hambatan dalam akses memperoleh pendidikan baik dalam bidang legislatif dan dalam bidang lainnya (Manfred Nowak;1995). Transformasi efektif nilai-nilai HAM dibidang pendidikan harus didasarkan pada asas ketersediaan (availibility), kesempatan memperoleh (accessability), asas penerimaan (acceptability) dan asas penyesuaian berdasarkan kondisi negara, lingkungan sosial dan interaksi kultural senyatanya, sehingga aplikasi dari penerapan nilai-nilai tersebut dalam pendidikan justru menjadi hak asasi manusia yang fundamental yang eksistensinya tidak dapat dikurangi dalam keadaan apapun (non derogable right).
Secara substansial, pengajaran HAM melalui jenjang pendidikan formal harus tempatkan pada substansi dasar dari HAM itu sendiri, yaitu hak untuk hidup dan bagaimana bisa mempertahankan diri dan berkembang secara alamiah. Konsep pengajaran HAM ini memiliki dua komponen dasar, yaitu konsep "pengembangan secara keseluruhan" (holistic approach) dari dari anak dalam pendidikan dan konsep ketersediaan sarana (accessibility) bagi pemenuhan pengembangan secara keseluruhan dari suatu negara (S. Detrick, ;1999). Konsep penegembangan secara keseluruhan dapat diartikan bahwa tujuan pendidikan harus mencakup pengembangan moral, spiritual, kecerdasan serta perkembangan sosial dalam masyarakat berdasarkan pada keadaan obyektif dari anak. Konsep ketersediaan sarana menekankan bahwa negara menjamin adanya ketersediaan sumberdaya semaksimal mungkin untuk mengembangkan pribadi anak secara keseluruhan. Komite Internasional Hak Anak, dalam hal ini juga memberikan penafsiran resmi bagi negara dalam merumuskan tujuan pendidikan berdasarkan konsep pengembangan secara keseluruhan bagi anak dalam Pasal 29 Konvensi (The Committee of the Right of the Child). Atau singkatnya, Komite menekankan bahwa 'toleransi (tolerance), keanekaragaman (diversity), dan obyektivitas (objectivity) haruslah secara seimbang ditekankan dalam pendidikan bagi anak untuk mencapai kematangan fisik, mental, spiritual dan emosional untuk dapat berpartisipasi secara aktif dan 
bertanggung jawab dalam masyarakat yang bebas.

\section{Hak Pendidikan di Wilayah Perbatasan Dalam Kerangka Konstitusi Republik Indonesia}

Dalam konteks legal, pemenuhan hak atas pendidikan merupakan sesuatu yang justisiabel bagi setiap orang untuk menerima, memperoleh dan menikmati pendidikan. Di lain pihak, negara berkewajiban untuk memenuhinya. Kualitas dan kuantitas pendidikan wajib dipenuhi oleh pemerintah sebagai penyelenggara negara. Pemahaman dalam kerangka pemahaman kolektif bahwa pendidikan sebagai sebuah hak akan memposisikan pendidikan sebagai sebuah kebutuhan bersama yang akan menentukan masa depan bangsa dan Negara Indonesia.

Pendidikan selain merupakan bagian dari hak asasi, di sisi lain juga merupakan prasyarat bagi pelaksanaan, pemajuan dan perlindungan hak asasi manusia (Hillary Rodham;1973). Tingkat pendidikan dari orang perorang dan kolektif sebagai sebuah bangsa terbukti mempengaruhi pemajuan dan perlindungan hak asasi manusia (Committee on Economic, Social and Cultural Rights). Demikian pula terhadap pemenuhan dan pemajuan hak ekonomi sosial dan budaya, pendidikan menjadi prasyarat utama bagi perealisasiannya. Toleransi, kesadaran dan pengembangan manusia seutuhnya menjadi tujuan penting pendidikan menurut Komite Hak Ekonomi, Sosial dan Budaya. Disamping itu, hak atas pendidikan di setiap tingkatan juga merupakan sarana yang paling penting untuk menciptakan suatu kebudayaan hak asasi yang universal (Van Bueren ;1995).

Kewajiban tersebut berdasarkan pada aplikasi prinsip-prinsip dasar pemajuan dan perlindungan terhadap pilar-pilar dasar hak asasi manusia, yaitu kebebasan, kesamaan dan integritas. Ketiga dasar tersebut melahirkan semangat untuk menghormati (to respect) dan memenuhi (to fulfil) terhadap pemenuhan hak ekonomi, sosial dan budaya berdasarkan tiga kewajiban utama yaitu kewajiban pencapaian hasil (obligation of result), kewajiban melaksanakan kemauan dalam Konvensi (obligation of conduct) dan kewajiban pelaksanaan kewajiban-kewajiban tersebut secara transparan di dalam pengambilan keputusan (obligation transparent assessment of progress) terhadap indikator pemanfaatan dan pengunaan sumber daya maksimal yang tersedia (maximum available resources). Secara khusus, Indonesia terikat untuk melaksanakan kewajiban dalam pemenuhan hak atas pendidikan berdasarkan kewajiban untuk "undertakes to take steps, to the maximum of its available resources, with a view to achieving progressively the full realization of the rights recognized in the present Covenant.

Terbukanya akses pendidikan bagi semua warga negara merupakan conditio sine qua non dihargainya nilai kebebasan dan keadilan. Selama masih ada warga negarayang tidak dapat memperoleh akses pendidikan, meski di tingkat paling dasar, negara merupakan instansi yang paling bertanggung jawab atas 
ketidakadilan ini. Tanpa dijaminnya kebutuhan dasar ini, partisipasi warga dalam iklim demokrasi yang memungkinkan terjadinya pergerakan sosial ke atas kian jauh dari harapan. Yang miskin akan semakin miskin, yang tak berdaya akan semakin terperdaya. Dalam masyarakat demokratis, politik merupakan ekspresi kepercayaan publik, berupa amanah untuk menyejahterakan warganya, termasuk peningkatan kualitas pendidikan dan penguatan civil society (terbukanya peluang yang sama bagi tiap warga untuk aktif secara politis). Tanpa usaha ini, politik berubah menjadi wahana penguasaan sumber-sumber alam dan sosial bagi kepentingan segelintir orang. Karena itu, akses pendidikan bagi semua warga merupakan prioritas dasar sebab dengannya dijamin persamaan. Persamaan dalam mengenyam pendidikan memungkinkan tiap warga menghayati kebebasannya sehingga mereka mampu aktif berperan serta dalam kehidupan demokratif yang kian mengukuhkan martabat mereka sebagai manusia (Scot Colnan, 2008).

Berkaitan dengan hal tersebut di atas, penghapusan diskriminasi perlu kiranya dilakukan dengan memberi kesempatan yang seluas-luasnya kepada setiap warga negara untuk mengenyam pendidikan, sehingga sekolah murah, bahkan gratis, akan tercipta bagi segenap rakyatnya tanpa terkecuali. Oleh karenanya pemerintah dituntut untuk bisa berlaku adil dengan memberikan kesempatan yang sama bagi setiap warga negara untuk menempuh pendidikan (formal) dan mampu melindungi serta menjamin hak-hak warga negara terutama bagi mereka yang secara finansial tidak mampu supaya tetap bisa menempuh pendidikan yang layak (Sujatmoko,;2006).

Pemerataan pendidikan merupakan isu paling kritis karena berkait erat dengan isu sensitif, yakni keadilan dalam memperoleh akses pendidikan (Masenus Arus, 2001). Memperoleh pendidikan yang layak merupakan hak asasi setiap warga bangsa yang dijamin konstitusi. Maka, pemerintah wajib memberi pelayanan pendidikan yang baik kepada seluruh masyarakat. Pendidikan menurut Pasal 1 angka 1 UU Nomor 20 Tahun 2003 tentang Sistem Pendidikan Nasional adalah usaha sadar dan terencana untuk mewujudkan suasana belajar dan proses pembelajaran agar peserta didik secara aktif mengembangkan potensi dirinya untuk memiliki kekuatan spiritual keagamaan, pengendalian diri, kepribadian, kecerdasan, akhlak mulia, serta keterampilan yang diperlukan dirinya, masyarakat, bangsa dan negara. Dengan demikian, pendidikan dapat diartikan baik sebagai proses maupun sebagai tahap khusus dalam proses tersebut.

Pada mulanya, pendidikan merupakan tanggung jawab masyarakat dan penduduk sebagai bentuk pemindahan keterampilanketerampilan teknis yang diperlukan untuk menjalankan tugas dalam kehidupan sehari-hari, pemindahan nilai-nilai agama, filosofi, sosial dan budaya dari masyarakat dan penduduk tersebut kepada generasi yang lebih muda (Gatut Saksono, 2008). Baru setelah munculnya 
negara modern, pendidikan dianggap merupakan sebuah masalah publik yang pemenuhannya merupakan kewajiban negara. Pandangan bahwa pendidikan merupakan kewajiban negara disepakati baik oleh konsep liberal HAM maupun konsep sosialisme HAM. Dalam pandangan konsep liberal HAM, kewajiban negara untuk memenuhi hak pendidikan diletakkan berdampingan dengan kewajiban yang dimiliki oleh orang tua dalam memberikan pendidikan bagi anak-anak mereka (Yuli Fajar Susetyo;2010).

Kewajiban negara dalam hal ini adalah lebih pada aspek menjamin bahwa setiap anak menerima pendidikan yang cukup melalui pengaturan formal terhadap kurikulum sekolah-sekolah. John Stuart Mill (2005) melukiskan hubungan antara kewajiban negara dan kewajiban orang tua dalam pendidikan tersebut sebagai berikut:"Jika pemerintah gigih menuntut hak pendidikan yang baik bagi setiap anak, maka pemerintah dapat mengusahakan sendiri suatu pendidikan yang baik. Pemerintah dapat menyerahkan kepada para orang tua kemungkinan untuk memperoleh pendidikan di mana dan sebagaimana mereka sukai dan merasa puas dengan membantu membayar uang sekolah anak-anak dari golongan yang lebih miskin dan membiayai seluruh biaya sekolah mereka (Leo Zwaak, 2001). Sedangkan dalam pandangan sosialisme, pemenuhan hak atas pendidikan merupakan salah satu tugas utama negara. Pengaruh yang cukup besar dari ideologi sosialisme terhadap pemikiran founding fathers Indonesia menyebabkan pandangan inilah yang diterima dan dirumuskan sebagai salah satu tujuan negara Indonesia sebagaimana termuat dalam Pembukaan UUD 1945.

Tujuan pendidikan adalah untuk memungkinkan setiap manusia dapat mengembangkan martabat dan kepribadiannya secara bebas sehingga secara aktif dapat berpartisipasi dalam suatu masyarakat yang bebas dan mengupayakan hidup yang toleran dan menghormati HAM (Elsam, 2005). Deklarasi Universal Hak Asasi Manusia (Duham) juga mengakui bahwa tujuan dan sasaran pendidikan mempunyai kaitan dengan HAM. Dalam Pasal 26 ayat (2) Duham ditetapkan bahwa:"Pendidikan hendaknya diarahkan pada pengembangan kepribadian secara penuh dan untuk memperkuat penghormatan terhadap hak asasi manusia dan kebebasankebebasan dasarnya. Pendidikan tersebut harus memajukan pemahaman, toleransi, dan persahabatan di antara semua bangsa, kelompok-kelompok agama, dan ras, dan hendaknya melanjutkan kegiatan-kegiatan Perserikatan Bangsa-Bangsa untuk mempertahankan perdamaian.

Sementara ICESCR dalam Pasal 13 ayat (1) menyebutkan bahwa pendidikan:“... harus diarahkan pada perkembangan kepribadian manusia seutuhnya dan kesadaran akan harga dirinya, dan memperkuat penghormatan atas hak-hak asasi dan kebebasan manusia yang mendasarbahwa pendidikan harus memungkinkan semua orang untuk berpartisipasi secara efektif dalam suatu masyarakat yang bebas, meningkatkan rasa pengertian, 
toleransi serta persahabatan antar semua bangsa dan semua kelompok, ras, etnis atau agama, dan lebih memajukan kegiatan-kegiatan Perserikatan Bangsa-Bangsa untuk memelihara perdamaian.'Dalam Pasal 3 UU No. 20 Tahun 2003 tentang Sisdiknas, disebutkan bahwa tujuan pendidikan nasional adalah untuk berkembangnya potensi peserta didik agar menjadi manusia yang beriman dan bertakwa kepada Tuhan Yang Maha Esa, berakhlak mulia, sehat, berilmu, cakap, kreatif, mandiri, dan menjadi warga negara yang demokratis serta bertanggung jawab (Harianti, ;2007). Kesemua tujuan tersebut hanya dapat dibentuk dan dikembangkan melalui pendidikan dasar dan menengah sebagai fondasi bagi pelaksanaan dan pencapaian tujuan pendidikan pada umumnya.

Pembagian HAM ke dalam 3 generasi yang pertama kali dicetuskan oleh Karel Vasak pada tahun 1979 memilah-milah HAM menjadi hak-hak sipil dan politik (generasi pertama), hak ekonomi, sosial dan budaya (generasi kedua), dan hak atas pembangunan atau hak solidaritas (generasi ketiga) (Indriyanto;2004). Hak atas pendidikan, meskipun dalam beberapa aspek dapat dimasukkan dalam generasi pertama, namun kesepakatan untuk memasukkan hak atas pendidikan sebagai salah satu jenis hak dalam generasi kedua. Kesepakatan untuk memasukkan hak atas pendidikan dalam generasi kedua HAM jelas sekali jika kita melihat pengaturan mengenai hal tersebut yang dimuat dalam ICESCR.
Sebagai salah satu jenis hak generasi kedua HAM, hak atas pendidikan tidak terlepas dari ciriciri yang melekat pada hak ekonomi sosial dan budaya. Secara klasik, generasi kedua dikenali dengan ciriciri sebagai berikut, yaitu: (a). Mencapai atau meraihnya dilakukan secara bertahap; (b). Campur tangan atau keaktifan negara sangat dituntut dalam pelaksanaannya; (c). Pelanggaran terhadapnya tidak bisa diajukan ke pengadilan; (d). Ketergantungan pada sumber daya yang ada; dan (d). Bersifat ideologis.Meskipun kesahihan dari ciri-ciri klasik sulit untuk dipertahankan, namun secara umum pelaksanaan hak-hak generasi kedua HAM memang tidak terlepas dari hal tersebut. Dengan demikian jelas bahwa campur tangan negara.

Namun ciri-ciri di atas hanya berupa generalisasi saja. Kajiankajian mutakhir menunjukkan bahwa ciri-ciri tersebut tidak selalu sahih. Hak ekonomi, sosial dan budaya tidak sepenuhnya merupakan hakhak positif karena cukup banyak hak yang dikategorikan sebagai hak tersebut menghendaki negara tidak ikut campur dalam hal tersebut. Sebagai contoh misalnya kebebasan memilih sekolah, kebebasan melakukan riset, dan sebagainya (Tanamas, 1999). Selain itu, meskipun hak-hak generasi kedua HAM mengakui pencapaian secara bertahap dan realitas keterbatasan sumber daya pada satu sisi, namun pada sisi yang lain ia menghendaki adanya efek segera, dan sama dengan hak sipil dan politik, pelanggaran terhadap ini dapat diajukan ke pengadilan. Sebagai contoh dapat kita lihat gugatan class action yang 
dilakukan berkenaan dengan tidak dipenuhinya ketentuan anggaran pendidikan minimal $20 \%$ dari APBN oleh pemerintah.

Kewajiban negara berkaitan dengan HAM adalah untuk melindungi, memajukan, memenuhi dan menghormati. Berkaitan dengan hak atas pendidikan kewajiban negara tersebut berkaitan dengan segala upaya agar hak tersebut dapat dinikmati oleh semua orang tanpa diskriminasi atau memerangi semua ketidakadilan yang ada dalam mengakses dan menikmati pendidikan. Kewajiban negara ini dapat diwujudkan melalui pembuatan peraturan-peraturan ataupun caracara lain untuk memajukan persamaan kesempatan dan perlakuan dalam pendidikan sebagaimana ditetapkan dalam Konvensi Melawan Diskriminasi dalam Pendidikan yang disepakati oleh Konferensi Umum UNESCO pada tanggal 14 Desember 1960 (Stephen Parker;1991).

Pasal 13 dan 14 ICESCR telah menetapkan kewajiban-kewajiban internasional yang mengikat setiap negara yang meratifikasi kovenan ini pada intinya adalah kewajiban untuk memberikan pendidikan pada setiap orang dan pemenuhan pendidikan dalam setiap jenjang dengan kemudahan pada obyek pendidikan seperti penyelenggaraan pendidikan dasar yang wajib dan cuma-cuma, pengembangan pendidikan lanjutan dan pelaksanaan komitmen melaksanakan pendidikan fundamental. Kegagalan negara dalam melaksanakan salah satu kewajiban tersebut di atas merupakan pelanggaran terhadap hak-hak tersebut. Selain terkena pelanggaran karena tidak menghormati hak tersebut, negara juga dapat dikatakan telah melakukan pelanggaran karena tidak melakukan perlindungan, di mana negara berkewajiban untuk mencegah pelanggaran hak atas pendidikan. Bahkan seringkali, negara bukan saja melakukan pembiaran terhadap tindakantindakan pelanggaran namun justru negara sendiri yang menjadi pelaku pelanggaran tersebut.

\section{Kesimpulan}

Kewajiban negara berkaitan dengan HAM adalah untuk melindungi, memajukan, memenuhi dan menghormati. Berkaitan dengan hak atas pendidikan kewajiban negara tersebut berkaitan dengan segala upaya agar hak tersebut dapat dinikmati oleh semua orang tanpa diskriminasi atau memerangi semua ketidakadilan yang ada dalam mengakses dan menikmati pendidikan. Kewajiban negara ini dapat diwujudkan melalui pembuatan peraturan-peraturan ataupun caracara lain untuk memajukan persamaan kesempatan dan perlakuan dalam pendidikan sebagaimana ditetapkan dalam Konvensi Melawan Diskriminasi dalam Pendidikan yang disepakati oleh Konferensi Umum UNESCO pada tanggal 14 Desember 1960. Dengan kebijakan pemerintahan saat ini yang ingin memulai pembangunan dari wilayah perbatasan dan wilayah terluar semestinya kondisi pemenuhan hak atas pendidikan bagi masyarakat di wilayah perbatasan menjadi salah satu prioritas. Dengan demikian diperlukan sebuah kajian untuk 
Jurnal Media Komunikasi Pendidikan Pancasila dan Kewarganegaraan

Volume 2, Nomor 1 April 2020

mendapatkan gambaran mengenai politik hukum dan kebijakan negara dalam memenuhi hak atas pendidikan dasar dan menengah bagi masyarakat di perbatasan Kalimantan Barat dengan Sarawak. Analisis situasi dan kebutuhan terhadap pemenuhan hak atas pendidikan

\section{Daftar Pustaka}

Anggreni, I. A. K. Mangku, D. G. S., \& Yuliartini, N. P. R. (2020). Analisis Yuridis

Pertanggungjawaban

Pemimpin Negara Terkait Dengan Kejahatan Perang Dan Upaya Mengadili Oleh Mahkamah Pidana Internasional (Studi Kasus Omar Al-Bashir Presiden Sudan). Jurnal Komunitas Yustisia, 2(3), 81-90.

Arianta, K., Mangku, D. G. S., \& Yuliartini, N. P. R. (2020). Perlindungan Hukum Bagi Kaum Etnis Rohingya Dalam Perspektif Hak Asasi Manusia Internasional. Jurnal

Komunitas Yustisia, 1(1), 93111.

Asdar, A. Transboundary Haze Pollution Di Malaysia Dan Singapura Akibat Kebakaran Hutan Di Provinsi Riau Ditinjau Dari Hukum Lingkungan

Internasional. Legal

Opinion, 3(1).

Baehr, Peter, Pieter Van Dijk, Adnan B. Nasution, Leo Zwaak, 2001, Instrumen Internasional Pokok Hak-hak Asasi Manusia, Yayasan Obor Indonesia, Jakarta.

Bambang Indriyanto, HAM Dalam Konteks Kurikulum Nasional dasar dan menengah di wilayah perbatasan negara di Provinsi Kalbar perlu dilakukan secara menyeluruh terhadap kebijakan, program, kegiatan dan pendanaan dalam pemenuhan hak atas pendidikan.

Dan Lokal, Jurnal Hukum dan HAM Bidang Pendidikan, Vol. 2 No. 3 Desember 2004.

Biro Hukum dan Organisasi Setjen Kemdikbud, "Monitoring dan Evaluasi Pemenuhan Hak Atas Pendidikan di Indonesia Tahun 2011", Biro Hukum dan Organisasi Setjen Kemdikbud, 2012.

Blokker and Schemers, International Institutional Law, Fourth Edition, Leiden, 2003, hlm. 1002-1003.

Bonanza Perwira Taihitu, "Penaatan Indonesia Pada StandarStandar Hak Asasi Manusia Internasional", Thesis Fisipol UI, Universitas Indonesia, 2003.

Budi Hermawan Bangun, 2006, Pengantar Hukum dan HAM, Fakultas Hukum Untan, Pontianak.

Colin Wringe, 2006, Moral Education: Beyond the Teaching Rights and Wrong, Springer.

Committe on Economic, Social and Cultural Rights, General Comments 15: The Rights To Water", UN Doc. E/C.12/2002/II, 2002, para. 36. Committee on Economic, Social and Cultural Rights General Comment 13, The Right to Education (Art. 13), 08/12/99, 
Jurnal Media Komunikasi Pendidikan Pancasila dan Kewarganegaraan

Volume 2, Nomor 1 April 2020

E/C.12/1999/10, CESCR， 8 December 1999, para 1; pernyataan ini didukung oleh the World Bank in Crying Out for Change, World Bank in three volumes (2002).

Committee on Economic, Social and Cultural Rights General Comment 13.

Convention Against Discrimination in Education 1960, dalam Geraldine Van Bueren, International Documents on Children, ( $2^{\text {nd }}$, eds $\left.), 1998\right)$.

Coomans and Kaminga (eds), Extraterritorial Application of Human Rights Treaties, Antwerp, 2004, hlm. 214 dan Reinisch, "Securing the Accountability of International Organizations", 7 Global Governance, 2001.

Danusaputro, St. Munadjat, (1980). Hukum Lingkungan, Buku I: Umum. Bandung: Binacipta.

Deklarasi Universal Hak Asasi Manusia 1948 dan Pasal 13 Kovenan Hak Ekonomi Sosial dan Budaya 1966.

Diah Harianti, "Presentasi HAM dan KTSP, Pelatihan HAM Bagi Guru Se Propinsi Sumatera Barat, Padang, Juni 2007.

Eide, Asbjorn, Catarina Krause, Allan Rosas, 1995, Economic, Social and Cultural Rights, A Textbook, Martinus Nijhoff, Dordrecht.

Elsam, 2005, "Ekspektasi yang Sirna”, Laporan Penegakan HAM 2005, Lembaga Studi dan Advokasi Masyarakat (Elsam), Jakarta.

Emanuel Sujatmoko, et. al, Hak Warga Negara untuk Memperoleh Pendidikan
Dasar, dalam Jurnal Hukum dan HAM Bidang Pendidikan Vol. 4 No. 1 Juni 2006, Biro Hukum dan Organisasi Departemen Pendidikan Nasional, Jakarta.

Gatut Saksono, 2008, Pendidikan yang Memerdekakan Siswa, Rumah Belaajar Yabinkas.

General Assembly Resolution 41/128 of 4 December 1986, see $<$ http://www.unhchr.ch/html.m enu3/b/74.htm $>$, United Nations, Human Rights: A Compilation of International Instruments (1993, Vol. I second Part).

Geraldine Van Bueren, The International law on the Rights of Child, (1995), 233; dan lihat Article 1 of the World Declaration on Education for All.

Gindling, Lothar, (1980). "Public Participation in Environmental Decision Making" in Trends in Environmental Policy and Law. Switzerland: IUCN, Gland.

Hardjasoemantri, K., \& Supriyono, H. (2014). Hukum Lingkungan.

Hardjasoemantri, Koesnadi, (1986). Aspek Hukum Peran Serta Masyarakat dalam Pengelolaan Lingkungan Hidup. Yogyakarta: Gadjah Mada University Press.

Hardjasoemantri, Koesnadi, (1999). Hukum Tata Lingkungan. Edisi Ketujuh. Cetakan Keempat Belas. Yogyakarta: Gadjah Mada University Press.

Heribertus Jaka Triyana, "Implikasi Hukum Ratifikasi Kovenan Hak Ekonomi Sosial dan 
Jurnal Media Komunikasi Pendidikan Pancasila dan Kewarganegaraan

Volume 2, Nomor 1 April 2020

Budaya Terhadap Pemenuhan Hak Atas Pendidikan di Indonesia", Jurnal Hukum dan HAM, Vol. 4 Nomor 1, Juni 2006, Juni 2006, ISSN 16934512.

Hillary Rodham, "Children Under the Law",43 Harvard Educational Review (1973).

Human Rights Committee, General Comment 3, Article 2, para 1, Implementation at the national level (Thirteenth session, 1981), Compilation of General Comments and General Recommendations Adopted by Human Rights Treaty Bodies, UN Doc. HRI/GEN/1/Rev.1 at 14 (1994), University of Minnesota Human Rights Library,

http://www1.umn.edu/humanrts -/gencomm/hrcom 13.htm.

Ida Bagus Wyasa Putra, 2003, Hukum Lingkungan Internasional: Perspektif Bisnis Internasional, Refika Aditama, Bandung

Ifdal Kasim dan Johanes Masenus Arus, 2001, Hak Ekonomi, Sosial dan Budaya", Esai-Esai Pilihan, Elsam.

Interpretation of the Agreement of March 25, 1951 between the WHO and Egypt: Advisory Opinion, ICJ Report 1980, para. 73.

Itasari, E. R. (2015). Memaksimalkan Peran Treaty of Amity and Cooperation in Southeast Asia 1976 (TAC) Dalam Penyelesaian Sengketa di ASEAN. Jurnal Komunikasi Hukum (JKH), 1(1).

Itasari, E. R. (2020). BORDER MANAGEMENT BETWEEN
INDONESIA AND

MALAYSIA IN

INCREASING THE

ECONOMY IN BOTH

BORDER AREAS. Jurnal

Komunikasi Hukum

(JKH), 6(1), 219-227.

John Baylis, Steve Smith, 2005, The Globalization of World Politics (3rd ed), Oxford University Press

Jurgen Friedrich, 2013, International Environmental "soft law", New York, Springer

Katarina Tomasevski, "Indicators" dalam Asbjorn Eide (et.all), 1995, Economic, Social and Cultural Rights, A Textbook.

Keppres Nomor 40 Tahun 2004 Tentang Rencana Nasional HAM RI dan Peraturan Presiden Nomor 23 tahun 2011 Tentang Aksi Nasional HAM tahun 2010-2015.

Kovenan Internasional tentang HakHak Ekonomi, Sosial dan Budaya yang termuat dalam Lembaran Negara Republik Indonesia Tahun 2005 Nomor 118, Tambahan Lembaran Negara Republik Indonesia Nomor 4557.

Krier, James E., (1970). Environmental Litigation and tile Burden of Proof in Law and the Environment. New York: Walker Publishing Company.

Lawson, "Out of Control, State Responsibility and Human Rights: Will the ILC's Definitions of the Act of State Meet the Challanges of the 21st Century?, dalam Castermans, Van Hoof and Smith (eds), The Role of 
Jurnal Media Komunikasi Pendidikan Pancasila dan Kewarganegaraan

Volume 2, Nomor 1 April 2020

Nations State in the 21st Century, Human Rights, International Organizations and Foreign Policies, Essay in Honor of Peter Baehr, Cambridge, MA, 1999.

Lotulung, Paulus Effendi, (1993). Penegakan Hukum Lingkungan oleh Hakim Perdata. Bandung: Citra Aditya Bakti.

Lummert, Rudiger, (1980). Change in Civil Liability Concept in Trends in Environmental Policy and Law. Switzerland: IUCN, Gland. Milieurecht, W.C.J. Tjeenk Willink, Zwolle, (1989).

M Santos Pais, "A Human Rights Conceptual Framework for Children's Rights" dalam UNICEF Innovative Essay No.9.

M. Freeman, "The Limits of Children's Rights, dalam The Ideologies of Children's Rights, 1992.

Manfred Nowak, "The Right to Education" dalam Asbjorn Eide (et.all),1995, Economic, Social and Cultural Rights, A Textbook.

Mangku, D. G. S. (2010). Pelanggaran terhadap Hak Kekebalan Diplomatik (Studi Kasus Penyadapan Kedutaan Besar Republik Indonesia (KBRI) di Yangon Myanmar berdasarkan Konvensi Wina 1961). Perspektif, 15(3).

Mangku, D. G. S. (2011). Peluang dan Tantangan ASEAN Dalam Penyelesaian Sengketa Kuil Preah Vihear Di Perbatasan Kamboja dan Thailand. Pandecta: Research Law Journal, 6(2).
Mangku, D. G. S. (2012). Suatu Kajian Umum tentang Penyelesaian Sengketa Internasional Termasuk di Dalam Tubuh ASEAN. Perspektif, 17(3).

Mangku, D. G. S. (2013). Kasus Pelanggaran Ham Etnis Rohingya: Dalam Perspektif ASEAN. Media Komunikasi FIS, 12(2).

Mangku, D. G. S. (2017). The Efforts of Republica Democratica de Timor-Leste (Timor Leste) to be a member of Association of Southeast Asian Nations (ASEAN) and take an active role in maintaining and creating the stability of security in Southeast Asia. Southeast Asia Journal of Contemporary Business, Economics and Law, 13(4), 18-24.

Mangku, D. G. S. (2018). Kepemilikan Wilayah Enclave Oecussi Berdasarkan Prinsip Uti Possidetis Juris. Jurnal Advokasi, 8(2), 150-164.

Mangku, D. G. S. (2018). Legal Implementation On Land Border Management Between Indonesia And Papua New Guinea According to Stephen B. Jones Theory. Veteran Law Review, 1(1), 72-86.

Mangku, D. G. S., \& Itasari, E. R. (2015). Travel Warning in International Law Perspective. International Journal of Business, Economics and Law, 6(4).

Mangku, D. G. S., \& Radiasta, I. K. (2019). Tanggung Jawab Negara terhadap Penembakan Pesawat MH17 berdasarkan 
Jurnal Media Komunikasi Pendidikan Pancasila dan Kewarganegaraan

Volume 2, Nomor 1 April 2020

Hukum

Internasional. Pandecta:

Research Law Journal, 14(1), 25-33.

Mangku, D. G. S., Triatmodjo, M., \& Purwanto, $\mathrm{H}$. (2018). Pengelolaan

Perbatasan Darat Antara Indonesia Dan Timor Leste Di Wilayah Enclave

Oecussi (Doctoral dissertation, Universitas Gadjah Mada).

Marzuki, "Permasalahan Pemenuhan Hak Atas Pendidikan di Wilayah Provinsi Kalimantan Barat", Makalah Forum Grup Discussion, Pemetaan Permasalahan Pendidikan Di Wilayah Perbatasan Negara, Setjen Kemdikbud, Hotel Park Jakarta, 23-24 November 2011.

Mochtar Kusuma Atmadja, 1982, Pengantar Hukum Internasional, Buku I, Binacipta, Bandung.

Muhammad Joni Zulchaina Z. Tanamas, 1999, Aspek Hukum Perlindungan Anak Dalam Perspektif Konvensi Hak Anak, PT Citra Aditya Bakti, Bandung.

Nickel, James W., 1987, Making Sense of Human Rights: Philosophical Reflection on the Universal Declaration of the Human Rights, The Regents of the University of California.

Phnom Penh Statement on the Adoption of the ASEAN Human Rights Declaration (AHRD), 18 November 2012; Tommy Koh, op.cit, no. 1, hlm. 18; Heppy Ratna, AICHR dan Penguatan Perlindungan HAM di ASEAN, http://news.antara.co.id/berita/ 1256362459/aichr-dan-

penguatan-perlindungan-hamdi-asean, 2009.

Purwanto, H., \& Mangku, D. G. (2016). Legal Instrument of the Republic of Indonesia on Border Management Using the Perspective of Archipelagic State. International Journal of Business, Economics and Law, 11(4).

Purwendah, E., Mangku, D., \& Periani, A. (2019, May). Dispute Settlements of Oil Spills in the Sea Towards Sea Environment Pollution. In First International Conference on Progressive Civil Society (ICONPROCS 2019). Atlantis Press.

Putusan Mahkamah Konstitusi dalam Perkara Nomor 012/PUUIII/2005 Mengenai Pengujian Undang-Undang Nomor 36 Tahun 2004 Tentang Anggaran Pendapatan Belanja Negara.

Rangkuti, Siti Sundari, (1987). Hukum Lingkungan dan Kebijaksanaan Lingkungan dalam Proses Pembangunan Hukum Nasional Indonesia. Disertasi untuk memperoleh gelar Doktor dalam Ilmu Hukum. Surabaya: Universitas Airlangga.

Robert McCorquodale, International Organizations and International Human Rights Law: One Giant Leap for Humankind, in Kaiyan Homi Kaikobad and Michael Bohlander, International and Power Perspective on Legal Order and Justice, Martinus Nijhoff Publishers, 2009. 
Jurnal Media Komunikasi Pendidikan Pancasila dan Kewarganegaraan

Volume 2, Nomor 1 April 2020

S. Detrick, A Commentary on the UN Convention on the Right of the Child, 1999.

Sakti, L. S., Mangku, D. G. S., \& Yuliartini, N. P. R. (2020).

TANGGUNG JAWAB

NEGARA TERHADAP

PENCEMARAN

LINGKUNGAN LAUT

AKIBAT TUMPAHAN

MINYAK DI LAUT

PERBATASAN INDONESIA

DENGAN SINGAPURA

MENURUT HUKUM LAUT

INTERNASIONAL. Jurnal

Komunitas Yustisia, 2(3), 131140.

Scot Colnan, 2008, The Effectiveness of Domestic Human Rights NGO's, Martinus Nijhoff Publisher, Leiden Boston.

Setiawati, N., Mangku, D. G. S., \& Yuliartini, N. P. R. (2020).

Penyelesaian

Sengketa

Kepulauan Dalam Perspektif Hukum Internasional (Studi Kasus Sengketa Perebutan Pulau Dokdo antara JepangKorea Selatan). Jurnal Komunitas Yustisia, 2(2), 241250.

Sisca Fitriyani, 2013, "Persepsi Mahasiswa Program

Kependidikan Universitas Pendidikan Indonesia Terhadap Program Sarjana Mendidik di Daerah Terdepan, Terluar dan Tertinggal", dalam repository.upi.edu/436/4/S_GE O 0900185_CHAPTER\% $\%$ 01 . pdf,

Stephen Parker, "How Can RightsTalk Help Children: An Academic Perspective", dalam Phillip Alston and H. Brennen,
The UN Children's Convention and Australia, 1991.

Taihitu, Bonanza Perwira,2003, Penaatan Indonesia pada Standar-Standar HAM Internasional Dalam Kurun Waktu 1991-2002, Thesis pada Fakultas Ilmu Sosial dan Politik Departemen Ilmu Hubungan Internasional, Pasca Sarjana Universitas Indonesia.

The Committee of the Right of the Child, General Comment No. 1, $C R C / G C / 2001 / 1,17$ April 2001.

Theo Huijbers, 1990, Filsafat Hukum, Penerbit Kanisius, Yogyakarta.

Todd Landman, 2006, Studying Human Rights, Oxford University Press.

Undang-Undang Nomor 20 tahun 2003 tentang Sistem Pendidikan Nasional.

UNICEF, 1998, A Human Rights Approach to UNICEF Programming for Children and Women : What It is and Some Changes It Will Bring.

United Nation Environment Programme, Training Manual on International Environmental Law, Division of Environmental Policy \& Law, Kenya.

United Nations, 1998, Human Rights, Questions and Anwers, United Nations Department of Public Information, New York.

Widayanti, I. G. A. S., Mangku, D. G. S., SH, L. M., Yuliartini, N. P. R., \& SH, M. (2019). Penggunaan Tentara Anak Dalam Konflik Bersenjata Ditinjau Dari Perspektif Hukum Humaniter (Studi 
Jurnal Media Komunikasi Pendidikan Pancasila dan Kewarganegaraan Volume 2, Nomor 1 April 2020

Kasus: Konflik Bersenjata Di

Sri Lanka). Jurnal Komunitas Yustisia, 2(1).

Wiratmaja, I. G. N. A., Mangku, D.

G. S., \& Yuliartini, N. P. R.

(2020). PENYELESAIAN

SENGKETA MARITIME

BOUNDARY

DELIMITATION DI LAUT

KARIBIA DAN SAMUDERA

PASIFIK ANTARA COSTA

RICA DAN NICARAGUA

MELALUI MAHKAMAH

INTERNASIONAL. Jurnal

Komunitas Yustisia,2(1), 6069.

Yosep Adi Prasetyo, "Hak Ekosob dan Kewajiban Negara",

Pemerkuatan Hak Asasi

Manusia Untuk Hakim Seluruh Indonesia, Holiday Resort Lombok, 28-31 Mei 2012, hlm. 2-6 dan Beitz, Charles, The Idea of Human Rights, Oxford University Press, 2009.

Yuli Fajar Susetyo, "Pendidikan Humanis", Modul Pembelajaran Penataran Hak Asasi Manusia Bidang Pendidikan Se-Provinsi kalimantan Barat, Biro Hukum Hukum dan Organisasi Setjen Kemdikbud-UGM, 2010.

Yuliartini, N. P. R., \& Mangku, D. G. S. (2019). Tindakan Genosida terhadap Etnis Rohingya dalam Perspektif Hukum Pidana Internasional. Majalah Ilmiah Cakrawala Hukum, 21(1), 4149. 